\title{
OPTIMALISASI PENDIDIKAN AGAMA ISLAM MELALUI PENERAPAN MODEL INTEGRATED LEARNING SEBAGAI UPAYA MEMBENTUK KEPRIBADIAN MUSLIM PADA SISWA DI MTS. NEGERI PALASAH KABUPATEN MAJALENGKA
}

\author{
Yus Yusuf Zaeni Taziri \\ Sekolah Tinggi Agama Islam (STAI-PUI) Majalengka \\ prodipgba16@gmail.com
}

\begin{abstract}
Islamic religious education in schools has not played an optimal role because it is more theoretical, fragmented or less related to other subjects. the learning model is still conventional, which emphasizes cognitive knowledge only, rather than the formation of attitudes (affective) and habituation (psycho-motoric). Then it is time for Islamic religious education to apply appropriate learning models in order to shape the behavior and personality of students so that students have true Muslim personalities. One model of Islamic religious education learning that is considered capable of overcoming all these problems, including the integrated learning model.

This study has objectives, namely: 1) to find out about Muslim personalities, 2) to examine the role of Islamic religious education in the formation of student personality, 3) to examine how the process of applying the integrated learning model in Islamic religious education learning, 4) to determine student responses regarding the application of the integrated learning model in the learning of Islamic religious education.

This research is a qualitative research using classroom action research (CAR), conducted at MTs. Negeri Palasah Majalengka Regency with 35 VIII-5 grade subjects. the data analysis technique uses non-statistical analysis techniques, namely in the form of descriptive analysis.
\end{abstract}


In this regard, the authors make a hypothesis, namely: "the optimization of Islamic religious education through the application of an integrated learning model can shape the Muslim personality of students in MTs. Negeri Palasah Majalengka Regency".

Keywords: Islamic Religious Education, Integrated Learning Model, Muslim Personality.

\begin{abstract}
Abstrak
Pendidikan agama Islam di sekolah belum berperan optimal karena lebih banyak bersifat teoritik, terpisah-pisah atau kurang terkait dengan mata pelajaran lain, serta model pembelajarannya yang masih bersifat konvensional, yakni lebih menekankan pada pengetahuan kognitif semata, daripada pembentukkan sikap (afektif) serta pembiasaan (psiko-motorik). Maka sudah waktunyalah pendidikan agama Islam menerapkan model pembelajaran yang tepat dalam rangka membentuk perilaku dan kepribadian siswa sehingga siswa memiliki kepribadian muslim sejati. Salah satu model pembelajaran pendidikan agama Islam yang dinilai mampu mengatasi segala persoalan tersebut, di antaranya adalah model integrated learning.

Penelitian ini memiliki tujuan, yaitu: 1) untuk mengetahui mengenai kepribadian muslim, 2) untuk mengkaji peranan pendidikan agama Islam dalam pembentukkan kepribadian siswa, 3) untuk mengkaji bagaimana proses penerapan model integrated learning pada pembelajaran pendidikan agama Islam, 4) untuk mengetahui respon siswa mengenai penerapan model integrated learning pada pembelajaran pendidikan agama Islam.

Penelitian ini merupakan penelitian kualitatif dengan metode penelitian tindakan kelas (PTK), dilaksanakan di MTs. Negeri Palasah Kabupaten Majalengka dengan subjek siswa kelas VIII-5 sebanyak 35 siswa. teknik analisis datanya menggunakan teknik analisis nonstatistik, yaitu berupa analaisis deskriptif.

Berkaitan dengan hal tersebut, maka penulis membuat hipotesis, yaitu: "optimalisasi pendidikan agama Islam melalui penerapan model
\end{abstract}


integrated learning dapat membentuk kepribadian muslim pada siswa di MTs. Negeri Palasah Kabupaten Majalengka".

Kata kunci: Pendidikan Agama Islam, Model Integrated Learning, Kepribadian Muslim.

\section{PENDAHULUAN}

\section{a. Latar Belakang Masalah}

Dalam kehidupan sosial, semua tindakan manusia dibatasi oleh aturan atau norma untuk berbuat dan berperilaku sesuai dengan sesuatu yang dianggap baik oleh masyarakat. Namun demikian, di tengah kehidupan masyarakat kadang masih dijumpai tindakan-tindakan yang tidak sesuai dengan aturan atau norma yang berlaku pada masyarakat.

Akhir-akhir ini Indonesia tengah diramaikan oleh isu yang sebenarnya telah sejak lama diperdebatkan di berbagai kalangan namun kembali mencuat di ranah publik, yaitu mengenai hubungan sejenis, atau yang lebih populer disebut LGBT (lesbi gay biseksual dan transgender). Telah disepakati bersama, walaupun masih dalam perdebatan, bahwa LGBT merupakan salah satu dari sekian banyak bentuk atau jenis perilaku menyimpang, yang berorientasikan seksual. Telah jelas dan nyata bahwa keberadaan komunitas ini akan berdampak buruk bagi generasi muda Indonesia, khususnya para remaja atau siswa yang tengah dalam fase pencarian jati diri.

Dalam proses antisipasi meluasnya penularan perilaku menyimpang tersebut, tentu dalam hal ini memerlukan kerjasama berbagai pihak, baik itu dari guru, kepala sekolah, orangtua, masyarakat, bahkan hingga ke pihak pemerintah daerah. Harus disepakati terlebih dahulu, bahwa hal ini merupakan bencana besar, sehingga dengan kesadaran penuh, seluruh pihak dapat proaktif menangani dan menyelamatkan para generasi muda sesuai dengan wewenangnya.

Pendidikan melalui sekolah-sekolah memiliki beberapa program yang strategis untuk pembentukkan karakter sejak dini, 
baik yang bersifat intrakurikuler, salah satunya yaitu melalui pendidikan agama Islam, maupun ekstrakurikuler di antaranya ekstrakurikuler pramuka, paskibra, dan lainnya. Namun masalahnya adalah program-program yang bagus dan strategis tersebut, khususnya pada proses pembelajaran PAI belum terealisasi secara optimal, sehingga perannya sebagai mata pelajaran yang berorientasi pada pembentukkan nilai-nilai keimanan dan ketakwaan kepada Allah SWT serta akhlak mulia belum dapat dicapai secara efektif. Dampaknya banyak siswa atau remaja yang belum memiliki identitas atau konsep diri yang betul, sehingga mudah dipengaruhi oleh lingkungan.

Beberapa hal yang menyebabkan rendahnya peranan dan efektifitas pendidikan agama islam dalam membentuk siswa yang beriman dan bertakwa kepada Allah SWT serta berakhlak mulia di antaranya materi pembelajaran pendidikan agama islam yang lebih banyak bersifat teoritik, terpisah-pisah atau kurang terkait dengan mata pelajaran lain, serta model pembelajarannya yang masih bersifat konvensional, yakni lebih menekankan pada pengetahuan kognitif semata, daripada pembentukkan sikap (afektif) serta pembiasaan (psiko-motorik), sehingga pendidikan agama islam yang bertujuan untuk membentuk siswa yang memiliki pengetahuan tentang ajaran agama islam serta mampu mengaplikasikannya dalam bentuk akhlak mulia belum dapat tercapai.

Upaya untuk mengkaji kembali pelaksanaan pembelajaran pendidikan agama islam di lembaga pendidikan formal terutama, semakin mendesak dan darurat jika dikaitkan dengan kenyataan di lapangan, dimana kini tengah terjadi degradasi moral yang ditandai dengan semakin meningkatnya kejahatan atau kriminalitas yang sebagian besar dilakukan oleh para remaja atau pelajar seperti tawuran, penyalahgunaan narkoba dan minuman keras, pergaulan bebas, bahkan kejahatan seksual. Salah satu penyebab utama dari semua hal yang terjadi tersebut adalah kegagalan pendidikan agama islam dalam memberikan pendidikan dan pembelajaran yang bermakna, sehingga siswa 
gagal menemukan identitas dirinya, yang pada akhirnya perilakunya dengan mudah dapat dipengaruhi dan menjadi salah satu penyebab timbulnya perilaku-perilaku menyimpang.

Berdasarkan hal tersebut, tentu yang harus segera dilakukan oleh semua pihak adalah sungguh-sungguh melaksanakan dan memfungsikan program-program secara maksimal demi terbentuknya siswa sehat, cerdas, berprestasi, dan beriman dan takwa kepada Allah SWT. Kaitannya dengan kondisi tersebut, maka sudah waktunyalah pendidikan agama islam menerapkan model pembelajaran yang tepat dalam rangka membentuk perilaku dan kepribadian siswa sehingga siswa memiliki kepribadian muslim sejati.

Salah satu model pembelajaran pendidikan agama Islam yang dinilai mampu mengatasi segala persoalan tersebut, di antaranya adalah model integrated learning. Oleh Karena itu, penulis tertarik untuk merubah pola pembelajaran pendidikan agama islam yang konvensional menuju model pembelajaran terpadu, sehingga diharapkan mampu menciptakan suasana pembelajaran yang menyenangkan, mampu meningkatkan pemahaman siswa karena kaya akan pengetahuan dan wawasan yang saling berkaitan satu sama lain, dan pada akhirnya mampu membantu siswa memecahkan berbagai masalah dalam proses pembelajarannya.

\section{b. Tujuan Penelitian}

Pembahasan mengenai optimalisasi pendidikan agama Islam melalui penerapan model integrated learning sebagai upaya untuk membentuk kepribadian siswa ini memiliki beberapa tujuan, yaitu:

1. Untuk mengkaji bagaimana proses penerapan model integrated learning pada pembelajaran pendidikan agama Islam.

2. Untuk mengetahui respon siswa mengenai penerapan model integrated learning pada pembelajaran pendidikan agama Islam. 


\section{Metodologi Penelitian}

Penelitian mengenai optimalisasi pendidikan agama Islam melalui penerapan model integrated learning sebagai upaya pembentukkan kepribadian muslim ini dilaksanakan di MTs. Negeri Palasah Kabupaten Majalengka. Pada penelitian ini penulis menggunakan metode penelitian tindakan kelas (PTK) yang memiliki langkah-langkah sistematis atau disebut dengan rancangan siklus, yang terdiri dari tahap perencanaan (planning), pelaksanaan tindakan (action implementation), pengamatan (observasi), dan refleksi (reflection). Berikut desain penelitian tindakan kelas (PTK).

\section{Bagan I}

Desain Penelitian Tindakan Kelas

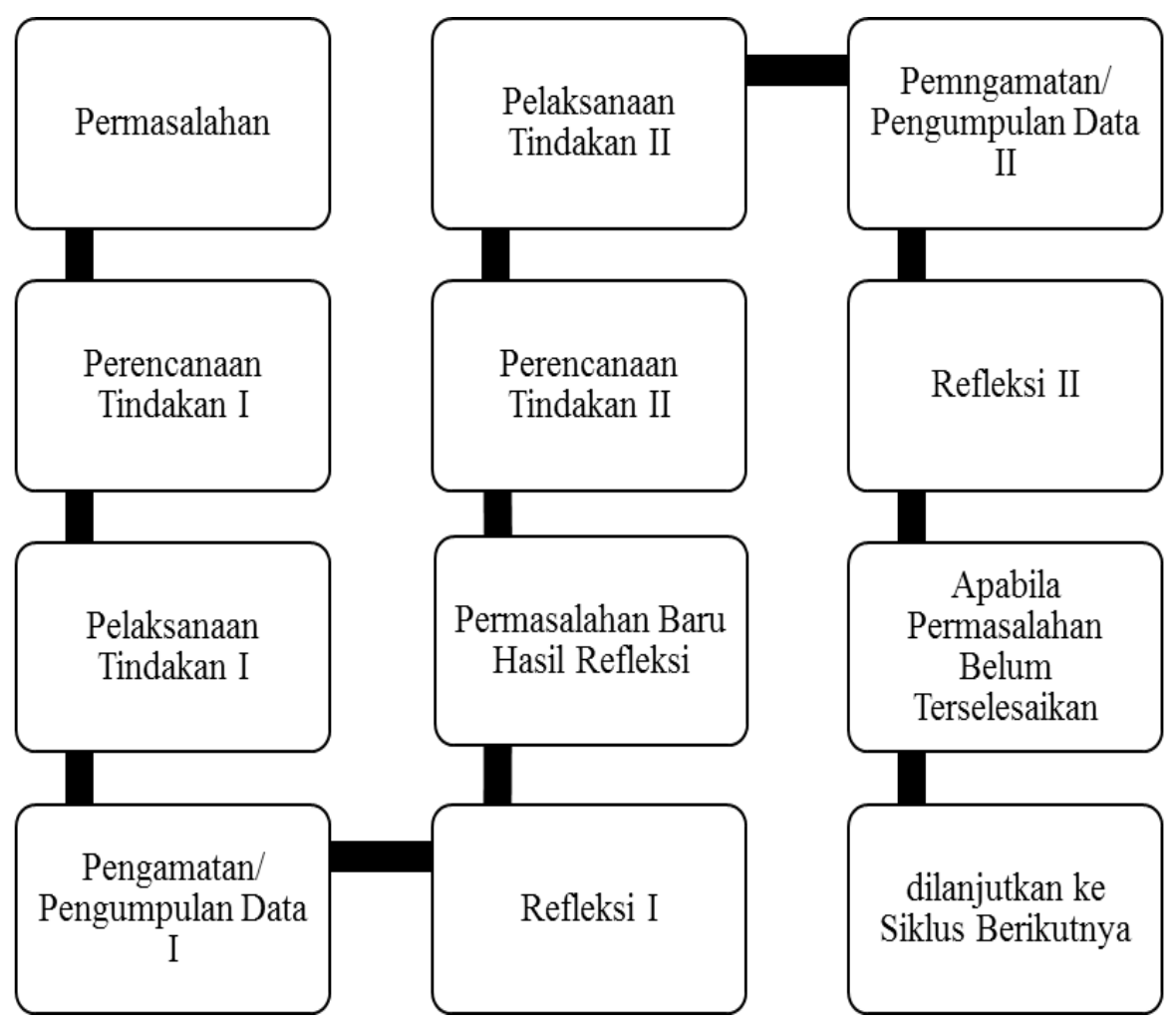


Dalam suatu penelitian diperlukan sebuah subjek yang akan diteliti untuk memperoleh data. Adapun subjeknya adalah siswa kelas VIII-5 MTs Negeri Palasah Kabupaten Majalengka. Subjek penelitian tindakan kelas (PTK) ini di kelas VIII-5 dengan jumlah 35 siswa dengan komposisi perempuan 18 orang dan laki-laki 17 orang. Peneliti memilih kelas VIII-5 sebagai subjek penelitian dengan berdasarkan pada tingkat kenakalan siswa yang lebih banyak dibandingkan dengan kelas yang lainnya.

Instrumen yang digunakan dalam penelitian ini terdiri dari lembar observasi sikap, lembar angket, dan pedoman wawancara. Penelitian ini merupakan jenis penelitian kualitatif dengan menggunakan metode penelitian tindakan kelas (PTK), dan teknik analisis datanya menggunakan teknik analisis non-statistik, yaitu berupa analaisis deskriptif. Dalam rangka memperkuat analisis data dari penyebaran angket bagi siswa, maka penulis akan menggunakan analisis data statistic sederhana, yaitu teknik pengumpulan data penyusunan, penyajian, dan penganalisaan berdasarkan hasil angket. Dalam hal ini akan menggunakan rumus prosentase.

\section{Hasil dan Pembahasan}

Al-syaibani mengatakan bahwa tujuan pendidikan Islam adalah untuk mempertinggi nilai-nilai akhlak hingga mencapai nilai akhlak al-karimah. Berikut beberapa tujuan dalam pendidikan Islam di antaranya:

a. Membimbing manusia agar dapat menempatkan diri dan berperan sebagai individu yang taat dalam menjalankan ajaran agama Allah SWT.

b. Membentuk sikap takwa kepada Allah SWT.

c. Menumbuhkan pola kepribadian manusia yang sempurna (insan kamil).

d. Menegakkan kebenaran dalam rangka membentuk manusia yang berbudi luhur menurut ajaran Islam.

e. Penguasaan ilmu terhadap agama Islam. 
f. Mencapai keseimbangan pertumbuhan pribadi manusia secara menyeluruh melalui latihan-latihan kejiwaan, akal pikiran, kecerdasan, dan pancaindera.

g. Pembentuk kepribadian yang berakhlakul karimah.

h. Menopang keselamatan dan kesejahteraan hidup di dunia sesuai dengan perintah syari'at islam.

i. Memiliki keterampilan yang serasi dengan bakat yang dimiliki ${ }^{4}$.

Terdapat beberapa pendapat mengenai pendekatan integrated learning, yang intinya bahwa integrated learning merupakan suatu pembelajaran yang memadukan berbagai materi dalam sajian pembelajaran yang menyeluruh. Tujuan dari pembelajaran dengan menggunakan pendekatan integrated learning adalah agar siswa memahami keterkaitan antara mata pelajaran satu dengan mata pelajaran yang lainnya, atau materi pelajaran satu dengan materi pelajaran yang lainnya untuk mengembangkan kemampuan siswa agar menjadi pribadi-pribadi integrated, yaitu manusia yang selaras dengan lingkungannya.

Maryanto mengatakan bahwa dalam pembelajaran integrated learning disusun secara keseluruhan dalam satu tema yang mengandung suatu pertanyaan atau masalah yang akan dipelajari. Langkah-langkah dalam penyusunan tema dalam pembelajaran integrated learning sebagai berikut:

1. Memilih pusat kendali

Guru mengawali kegiatan dengan memilih pusat kendali yang berfungsi sebagai pusat pandang bagi pengembangan materi pelajaran.

2. Menentukan hubungan

Guru menentukan mata rantai penghubung yang tertuju pada tema dalam bentuk pertanyaan topic, ide, atau orang atau benda yang kesemuanya cukup pendek yang tertuju pada tema.

3. Menentukan pertanyaan-pertanyaan terpadu 
Untuk menguatkan keterkaitan antar materi pelajaran dapat juga dengan memunculkan pertanyaan-pertanyaan umum sampai pertanyaan pokok yang terkait dengan tema dan materi pelajaran. 4. Menuliskan kegiatan sebagai dasar pelaksanaan pembelajaran ${ }^{9}$.

Terkait dengan kegiatan yang akan dilaksanakan dalam pembelajaran di sekolah, sebaiknya tema yang dipilih sesuai dengan lingkungan dan kondisi yang ada sehingga memudahkan dalam menetukan kegiatan-kegiatan yang sesuai dengan tujuan pembelajaran yang diinginkan.

Pada dasarnya kepribadian tidak terbentuk begitu saja, melainkan terbentuk melalui proses kehidupan yang panjang. Oleh karena itu, banyak faktor yang turut ambil bagian dalam pembentuk kepribadian manusia tersebut. Oleh karena itu, terlepas bagaimana dan seperti apa kepribadian seseorang itu, apakah kepribadiannya baik, buruk, kuat, lemah, lurus, ataupun menyimpang, sepenuhnya ditentukan oleh faktor yang mempengaruhi dalam pengalaman hidup seseorang tersebut. Faktor-faktor yang mempengaruhi kepribadian seseorang itu berasal dari dalam (internal) dan dari lingkungannya (eksternal). Dalam hal ini, pendidikan sangat besar penanamannya untuk membentuk kepribadian manusia itu ${ }^{12}$.

Dalam rangka merealisasikan pembentukkan kepribadian dalam pendidikan Islam, diperlukan tiga proses dasar pembentukan:

- Pembentukan pembiasaan

Pembentukan pembiasaan dilaksanakan melalui kegiatan pembinaan siswa melalui kegiatan sholat berjamaah, anjuran berpuasa, tadarus, dan lain sebagainya. Dalam pelaksanaannya, keluarga dan sekolah harus bekerja sama dan konsisten dalam mengkondisikan hal tersebut.

- Pembentukan pengertian

Pembentukan yang meliputi sikap dan minat untuk memberi pengertian, nasehat, diskusi, dan lainnya tentang aktifitas yang akan dilaksanakan, agar seseorang terdorong ke arah perbuatan yang lebih positif. Dalam pembentukkan pengertian ini pun perlu adanya konsistensi antar pribadi. 
- Pembentukan kerohanian yang luhur

Pembentukan ini merupakan sebuah pergerakan untuk membentuk dan membangun sifat takwa yang mengandung nilai-nilai luhur, seperti jujur, toleransi, ikhlas, sabar, menepati janji, peduli, adil, dan bertanggung jawab.

Proses pembentukan kepribadian dalam pendidikan Islam berlangsung secara bertahap dan berkesinambungan. Dengan demikian, pembentukan kepribadian merupakan rangkaian kegiatan yang saling berhubungan dan saling tergantung sesamanya.

Upaya untuk menjadi diri sendiri harus dimulai dari proses berpikir mengenai tujuan hidup dirinya sendiri. Kepribadian mutlak dibentuk untuk sebuah peningkatan kualitas hidup. Adapun tujuan yang diharapkan dalam membentuk kepribadian siswa sebagai muslim yaitu:

1. Membentuk sikap disiplin waktu.

2. Mampu mengendalikan hawa nafsu.

3. Memelihara diri dari perilaku menyimpang.

4. Mengarahkan hidup menuju kepada kebaikan dan tingkah laku yang benar.

5. Mempelajari perubahan-perubahan dalam gaya hidup.

6. Meningkatkan konsep diri, nilai-nilai diri, kebutuhan diri, agar dapat membantu orang lain melakukan hal yang sama.

7. Mengembangkan perasaan harga diri dan percaya diri melalui aspek dukungan dan tanggung jawab yang bersifat timbal balik.

Proses pembelajaran memiliki tujuan, yaitu untuk menjadikan siswa berpikir kritis, kreatif, dan bermakna. Untuk mencapai tujuan tersebut guru sebaiknya menggunakan pembelajaran yang banyak melibatkan siswa secara aktif dalam belajar, sehingga kegiatan pembelajaran tidak hanya bersumber dari guru, tetapi sebaliknya mampu menciptakan pembelajaran yang bersumber pada keaktifan siswa (student center learning).

Lebih jauh lagi, proses pembelajaran harus mampu memadukan dan mendemonstrasikan konsep-konsep materi yang dipelajari. Berkaitan dengan hal tersebut, banyak materi yang dipelajari melalui pengalaman nyata, disamping melalui logika 
imajinasi yang tidak dapat dilakukan melalui pengalaman nyata, akan tetapi kedua hal tersebut harus dipelajari karena saling terkait satu dengan yang lainnya dan harus dilakukan secara bersamaan sesuai dengan perkembangan otak kiri dan otak kanan.

Pendekatan integrated learning merupakan salah satu pembelajaran yang banyak melibatkan siswa secara aktif. Pembelajaran ini berdasarkan tema pilihan yang berhubungan dengan dunia nyata. Siswa diajak untuk memahami konsep-konsep pembelajaran melalui pengalaman langsung, saling bekerja sama dalam menyelesaikan permasalahan yang ada, dan mau mendengarkan serta menghargai pendapat orang lain. Dengan demikian model integrated learning diharapkan dapat meningkatkan hasil belajar siswa.

Beberapa tahapan model integrated learning melalui pembelajaran holistik, yaitu:

- Menentukan kompetensi dasar, hasil yang akan dicapai serta indikator sebagai bahan evaluasi.

- Menentukan tema dan judul.

- Menentukan sebuah tema yang dapat mempersatukan berbagai mata pelajaran dengan bebagai kompetensi dasar yang ingin dicapai.

- Memilih sebuah judul yang menarik, nyata, dan dekat dengan kehidupan anak.

- Membuat bagan keterjalaan melalui tema dari berbagai mata pelajaran yang dapat dijkaitkan satu sama lain, sesuai dengan tema yang dipilih.

- Kompetensi-kompetensi ini kemudian diintegrasikan dengan menggunakan model web (keterjalaan).

- Menyusun kegiatan belajar yang menarik bagi anak dan efektif dalam pencapaian kompetensi

- Kegiatan-kegiatan yang dilakukan harus sesuai dengan konsep student active learning, contectual learning, dan mencakup kecerdasan majemuk yang dimiliki anak.

- Mengkondisikan kegiatan belajar yang merupakan kombinasi dari kegiatan individu dan kelompok. Kegiatan kelompok dapat 
menumbuhkan dan meningkatkan aspek sosial anak, komunikasi, penggunaan bahasa, dan juga menumbuhkan motivasi anak untuk belajar.

Berkaitan dengan hal tersebut, penggabungan, pembahasan, serta pembelajaran secara menyeluruh antar materi pelajaran pendidikan agama Islam yang di dalamnya terdapat mata pelajaran fikih, akidah akhlak, Qur'an hadist, dan sejarah kebudayaan Islam, serta materi pada mata pelajaran lainnya diharapkan mampu menciptakan kegiatan pembelajaran yang bermakna. Pembelajaran bermakna akan mengeluarkan siswa dari sebuah kebingungan, sebaliknya pembelajaran bermakna akan mampu memberikan pemahaman pada siswa secara menyeluruh yang bermanfaat bagi pembentukan konsep diri, sekaligus kepercayaan diri siswa. Kejelasan konsep diri mampu membantu siswa menemukan identitas dirinya, dan lebih jauh lagi mampu membentuk kepribadiannya sebagai seorang muslim.

\section{Penutup}

Pendidikan agama Islam berperan sebagai salah satu program pemerintah dalam membentuk kepribadian siswa sebagai muslim. Namun masalah yang terjadi pada pendidikan agama Islam di antaranya materinya lebih banyak bersifat teoritik, terpisah-pisah atau kurang terkait dengan mata pelajaran lain, serta model pembelajarannya yang masih bersifat konvensional, yakni lebih menekankan pada pengetahuan kognitif semata, daripada pembentukkan sikap (afektif) serta pembiasaan (psiko-motorik), sehingga pendidikan agama islam yang bertujuan untuk membentuk siswa yang memiliki pengetahuan tentang ajaran agama islam serta mampu mengaplikasikannya dalam bentuk akhlak mulia belum dapat tercapai.

Penggabungan, pembahasan, serta pembelajaran secara menyeluruh antar materi pelajaran pendidikan agama Islam melalui penerapan model integrated learning diharapkan mampu menciptakan kegiatan pembelajaran yang bermakna. pembelajaran bermakna akan mampu memberikan pemahaman pada siswa secara 
menyeluruh yang bermanfaat bagi pembentukan konsep diri, sekaligus kepercayaan diri siswa. Kejelasan konsep diri mampu membantu siswa menemukan identitas dirinya, dan lebih jauh lagi mampu membentuk kepribadiannya sebagai seorang muslim.

\section{DAFTAR PUSTAKA}

Arifin, M. 1994. Ilmu Pendidikan Islam. Jakarta: bumi Aksara.

Bastaman, Hana Djumhana. 2005. Integrasi Psikologi dengan Islam Menuju Psikologi Islam. Yogyakarta: Pustaka Pelajar.

Dakir. 2004. Perencanaan dan Pengembangan Kurikulum. Yogyakarta: Rineka Cipta.

Margono, S. 2002. Metodologi Penelitian Pendidikan. Jakarta: Rineka Cipta.

Maryanto, A. 1994. Kurikulum Lintas Bidang Studi. Jakarta: Gramedia Widiasarana Indonesia.

Megawangi, R. 2005. Pendidikan Holistik. Cimanggis: Indonesia Heritages Fondation.

Mubarok, Achmad. 2005. Psikologi Keluarga. Jakarta: Bina Rena Pariwara.

Mujib, Abdul. 2006. Kepribadian dalam Psikologi Islam. Jakarta: Raja Grafindo Persada.

Nasution. 1994. Asas-asas Kurikulum. Jakarta: bumi aksara.

Sapuri, Rafy. 2009. Psikologi Islam: Tuntunan Jiwa Manusia Modern. Jakarta: Raja Grafindo Persada.

Sugiyono. 2014. Metode Penelitian Kuantitatif, Kualitatif, dan $R \& D$. Bandung: Alfabeta.

Zuhairini, et.al. 1992. Filsafat Pendidikan Islam. Jakarta: Bumi Aksara. 